\title{
Thank You, Akira Hayami! The Xavier Database of Historical Japan
}

\section{By Satomi Kurosu, Miyuki Takahashi and Hao Dong}

To cite this article: Kurosu, S., Takahashi, M., \& Dong, H. (2021). Thank You, Akira Hayami! The Xavier Database of Historical Japan. Historical Life Course Studies, 11, 112-131. https://doi.org/10.51964/hlcs11113

\section{HISTORICAL LIFE COURSE STUDIES}

Content, Design and Structure of Major Databases with Historical Longitudinal Population Data

VOLUME 11, SPECIAL ISSUE 5, 2020

GUEST EDITORS

George Alter

Kees Mandemakers

Hélène Vézina 


\section{HISTORICAL LIFE COURSE STUDIES}

Historical Life Course Studies is the electronic journal of the European Historical Population Samples Network (EHPSNet). The journal is the primary publishing outlet for research involved in the conversion of existing European and nonEuropean large historical demographic databases into a common format, the Intermediate Data Structure, and for studies based on these databases. The journal publishes both methodological and substantive research articles.

\section{Methodological Articles}

This section includes methodological articles that describe all forms of data handling involving large historical databases, including extensive descriptions of new or existing databases, syntax, algorithms and extraction programs. Authors are encouraged to share their syntaxes, applications and other forms of software presented in their article, if pertinent, on the EHPS-Net website.

\section{Research articles}

This section includes substantive articles reporting the results of comparative longitudinal studies that are demographic and historical in nature, and that are based on micro-data from large historical databases.

Historical Life Course Studies is a no-fee double-blind, peer-reviewed open-access journal supported by the European Science Foundation (ESF, http://www.esf.org), the Scientific Research Network of Historical Demography (FWO Flanders, http://www.historicaldemography.be) and the International Institute of Social History Amsterdam (IISH, http://socialhistory.org/). Manuscripts are reviewed by the editors, members of the editorial and scientific boards, and by external reviewers. All journal content is freely available on the internet at hlcs.nl.

\section{Co-Editors-In-Chief:}

Paul Puschmann (Radboud University) \& Luciana Quaranta (Lund University)

hislives@kuleuven.be

The European Science Foundation (ESF) provides a platform for its Member Organisations to advance science and explore new directions for research at the European level. Established in 1974 as an independent non-governmental organisation, the ESF currently serves 78 Member Organisations across 30 countries. EHPS-Net is an ESF Research Networking Programme.

The European Historical Population Samples Network (EHPS-net) brings together scholars to create a common format for databases containing non-aggregated information on persons, families and households. The aim is to form an integrated and joint interface between many European and non-European databases to stimulate comparative research on the micro-level.

Visit: http://www.ehps-net.eu.
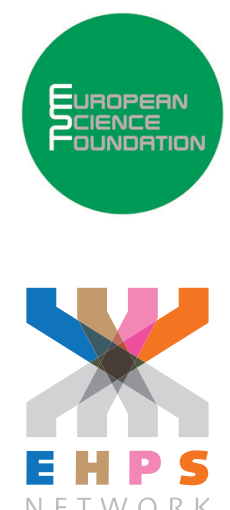


\title{
Thank You, Akira Hayami! \\ The Xavier Database of Historical Japan
}

\author{
Satomi Kurosu \\ Reitaku University \\ Miyuki Takahashi \\ Rissho University \\ Hao Dong \\ Peking University
}

\section{ABSTRACT}

This article introduces the Xavier database, one of the major sources for studying historical populations in Japan. The database consists of 162 years of annual observations for 28,105 individuals living in three villages and one town of the current Fukushima prefecture between 1708 and 1870 . We review the extensive efforts of the founder of Japanese historical demography, Akira Hayami, and his group in collecting, transcribing, coding, and finally making local population registers into this database for demographic analysis. We discuss the studies that flourished domestically and internationally using the data in the last two decades, followed by the discussion of current and promising development.

Keywords: Japan, Historical demography, Household registers, Longitudinal data

e-ISSN: $\quad$ 2352-6343

DOI article: $\quad$ https://doi.org/10.51964/hlcs11113

(C) 2021, Kurosu, Takahashi, Dong

This open-access work is licensed under a Creative Commons Attribution 4.0 International License, which permits use, reproduction \& distribution in any medium for non-commercial purposes, provided the original author(s) and source are given credit. See http://creativecommons.org/licenses/. 


\section{INTRODUCTION}

"Thank you, Francisco Xavier!" wrote Akira Hayami (1928-2019), the founder of Japanese historical demography in 1979. Without St. Francisco de Xavier who first brought Christianity to Japan in 1549, the Shumon-Aratame-Cho (SAC; religious affiliation investigation registers) would never have started. SAC was the "chance by-product of the Tokugawa Bakufu's fear and loathing of Christianity" (Hayami, 1979) which serves as the main source for Japanese historical demography. This article introduces the source, the construction, as well as the impact of the first digitized data set in Japanese historical demography. The data set was named after Xavier who was one of the founders of the Society of Jesus.

The construction of individual-level longitudinal data based on household registers, SAC and similar Ninbetsu-Aratame-Cho (NAC) for early modern Japan has opened up arrays of possibilities for investigating the demographic behavior of commoners in the Tokugawa period (1603-1867). Japanese historical demography has come a long way since Akira Hayami's application of the method of "family reconstitution" to Japanese household registers in the late 1960s. Hayami's lifetime collection of materials on historical demography from his earlier offices including Keio University, International Research Center for Japanese Studies (Nichibunken), and Reitaku Tokyo Center, are now hosted as the "Reitaku Archives" at Reitaku University, organized and maintained by the Population and Family History Project (PFHP) headed by Satomi Kurosu.

This article first introduces the sources used for the Xavier Database and the studies of Japanese historical demography in general. Particular attention is paid to how Hayami's collection of historical records, those which he called "treasure of humankind", were transcribed and put into a format with linked annual individual/household information. Next, we discuss the process of coding and construction of the Xavier Database, the first systematic database Hayami initiated in late 1980s. While there are numerous datasets and sources available across Japan by now, the sources for northeastern communities used for the Xavier Database are known to be the most detailed. We review the Xavier data, focusing on three villages (Niita, Shimomoriya, Hidenoyama) and one town (Koriyama) in the current Fukushima prefecture. Finally, we discuss how the studies based on the dataset advanced our understanding of people's lives through the analysis of behavior and organization of individuals, married couples, and households, as well as their influence on the studies of historical demography and family history.

\section{SOURCES}

Two primary sources used for the Xavier Database as well as studies of historical demography in Japan are SAC and NAC. ${ }^{1}$ Both of them are household registers and include basic information such as an individual's name, age, and relationship to the household head. A household can include not only kin members but also non-kin and servants. Notably, households can be registered even without any resident (e.g., actual residents left for work migration).

SAC was a religious investigation initiated around 1638 by the Tokugawa government as a measure to prevent the entry and spread of Christianity (Cornell \& Hayami, 1986; Hayami, 1979). The quality, dates of compilation, and availability of SAC vary depending on the village and region. Some SACs are based on de jure information and contain excess numbers of elderly persons, who, for example, outmigrated and possibly died elsewhere but are still listed in their households of origin. NAC preceded SAC and was a type of population register in nature similar to the contents of SAC, except that NAC excludes information on religious affiliation of individual villagers (Hayami, 2001). Meanwhile, NAC tends to record detailed information on population de facto. However, in most cases, it is not easy nor practical to distinguish between the two because the two sources are often indistinguishable and are indiscriminately compiled resulting in the title of the documents Shumon-Ninbetsu-Aratame-Cho.

$1 \quad$ Other sources not discussed in this article include temple death registers (Kako-Cho), pregnancy records (Kainin-Kakiage-Cho), records of population increase and decrease (Zogen-Cho), and Hokonin-Uke-Jo, a register of servants (hokonin) that recorded the contract detailing the type of service and length. Availability and accessibility of these sources vary greatly by region. When Zogen-Cho and HokoninUke-Jo were available, they were matched with SAC/NAC to either check the content or to supply additional information for analysis. 
It should be noted that unlike records of elites in other societies, both SAC and NAC documented "commoners". They include peasants, fishermen, merchants, etc., who were the majority of the population in 17th- to early 19th-century Japan. Tokugawa period was a highly stratified society. The elite bureaucrats and administrators during the Tokugawa period (samurai class), as well as the members of the Imperial court whose residency was segregated, were recorded separately from the commoners. ${ }^{2}$ The documents available today are copies of the SAC/NAC, kept in the hands of village officials after submitting them to local lords. The officials kept the register copies in order to add annotations for changes of individual vital events (e.g., birth, death, marriage, service) that would occur until the next survey. These annotations provide valuable information of vital records. However, the level of details in such registers differs by local government practices. For some han (domains, administrative units governed by daimyo, territorial lords), SAC was not always done every year. For other domains, only those after certain ages were registered (e.g., after age 15 for Maeda domain, after age 8 for Kishu and Hiroshima domains). The more detailed listings include origins and destinations of migrants with reasons (e.g., marriage, adoption, service), as well as household landholdings. According to Hayami (2001, p. 25), some of the best sources, in terms of quality and length (continuing more than one century with very few years missing in-between) come from the villages in Nihonmatsu domain (in current Fukushima prefecture), and this is where the very first attempt to systematically construct a database was made.

Figure $1 \quad$ Original "Ninbetsu-Aratame-Cho": Household No.112 in Niita, year 1763

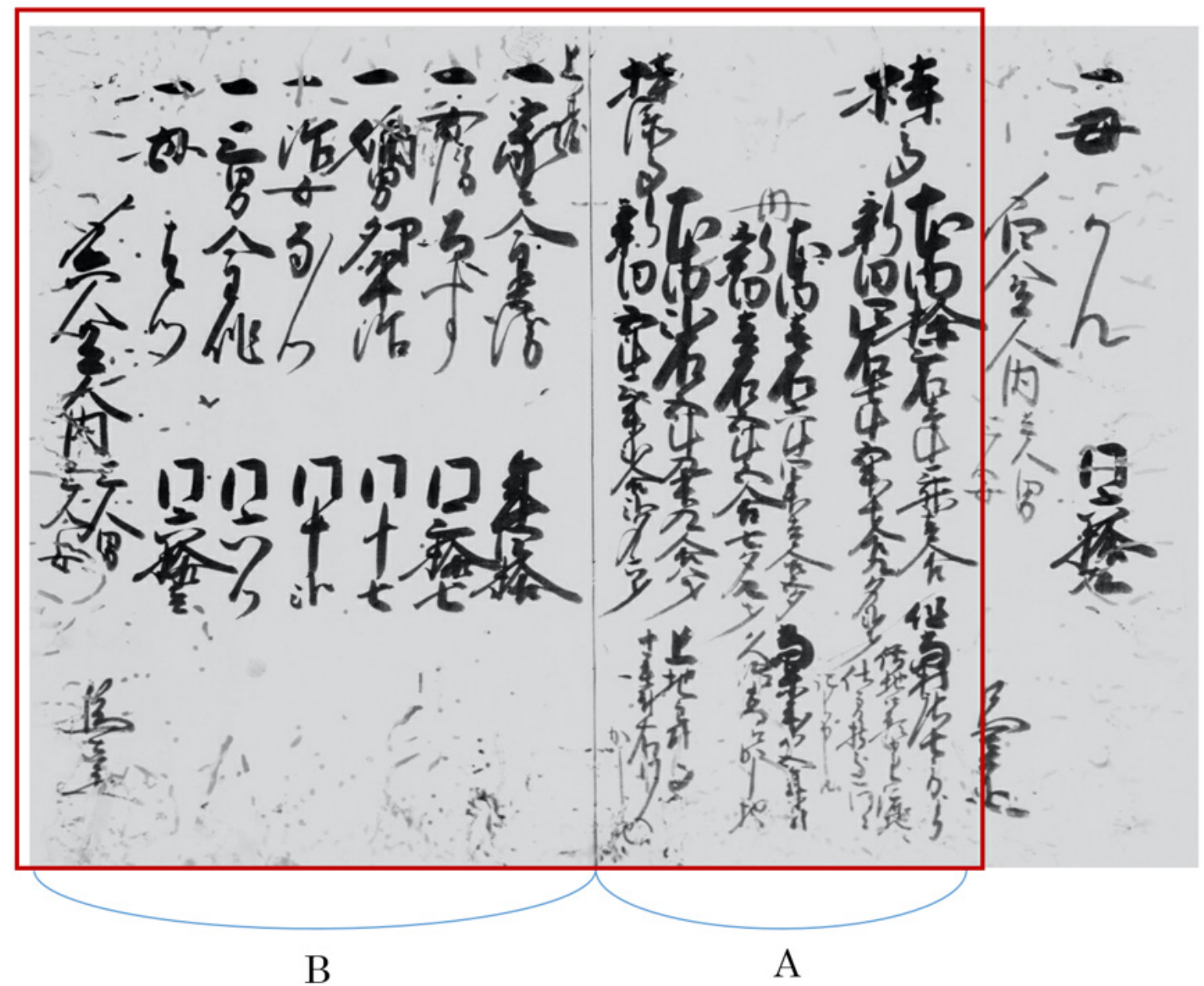

Source: Microfilm, Reitaku Archives, Population and Family History Project, Reitaku University.

Notes: NAC recorded information of all households in a village/town sequentially in one volume (book bound with Japanese paper) per year. The red square indicates one unit of household. Traditionally, the page reads from right to left. " $A$ " lists household landholdings and lands being leased/rent. " $B$ " lists each member of household. See text for details.

$2 \quad$ For studies of samurai demography and family, genealogies are often used. 
Figure 1 shows two pages of 1763 NAC in the village of Niita. The red square indicates one household unit. Reading from right to left, the unit starts with "A" which lists household landholding as well as lands being leased/rented, where "B" lists each household member with information about the relationship to the household head, name, and age. In this example, six household members are included: the household head (age 40), his wife (37), his first child-son (17), his second child-daughter (12), his third child-son (6), and his mother (61). The indication of the birth order of children suggests the importance of sibling hierarchy in the area. The column on the left side sums number of males and females in this household followed by number of horses.

\section{COLLECTION AND TRANSCRIPTION OF REGISTERS}

The collection of SAC/NAC was initiated and led by Akira Hayami in the late 1960-80s. It involved locating/finding SAC/NAC, contacting the holder, getting permission, and microfilming the materials. A great number of people of Hayami's research group have been involved in the collection of sources for over four decades. The sources for the Nihonmatsu domain in the Xavier Database were collected in local archives and private homes. The microfilms were then printed and transcribed into forms and numbers.

Since SAC/NAC registers provide annual information of household and individual life courses spanning up to 200 years, it was not easy to organize. Hayami's first trial was a manual organization of cards that tracked individual households per year (kohyo, not shown). Later on, he came up with the Basic Data Sheet (BDS) method of transcribing and organizing information of households for 25 years per sheet (see Figure 2). Hayami recalled that it was an "innovation" as it finally allowed researchers to track what was happening to the individuals and households "longitudinally". And, indeed, BDS was a breakthrough as a method for compiling detailed longitudinal information. It also opened up the opportunity for anyone with knowledge of contemporary Japanese to understand the content of these household registers, which otherwise would be hard to decipher without extensive training in early modern calligraphy. The annual information of a household member (name, relationship, age) is transcribed on the left panel of a BDS. Any movements or changes of status, including birth, death, marriage/adoption, and name changes, are annotated with a symbol and described at the bottom of the BDS. Any household members currently not residing in the household are placed in the right panel of the BDS with information of their locations and the reasons for not residing (for example, working as servant at other village/household). At the very right column of a BDS, the number of horses and the landholdings of the household are entered. SAC/NAC of the same household in the consecutive years are matched and transcribed following the previous year. Organized in this way, both the information of individuals and households can be tracked for the entire observation period.

The linkage of households from one year to the next was done by matching the order of appearance of the households and checking names and ages of household members. Once the BDS was written, individuals were given unique identifiers. When the linking of individual information was done manually this was done by coders; for example, matching and giving the same ID to an individual who left the household of origin and entered another household via marriage/service. Individuals were matched as long as the move took place within the village. Thus, BDS became a valuable source of longitudinal demographic information that follows intriguing life histories of commoners - like reading a biography.

Because it was before the computer revolution, most of Hayami's initial work was done manually extracting information from BDS to construct individual life courses and family. The ITS (individual tracing sheet, see Figure 3) was Hayami's invention for tracking individual movements. And, the FRF (Figure 4) follows the famous "family reconstitution form " of the French historical demographer, Louis Henry. These forms are still kept at the Reitaku Archives, although they are taken over by computer calculation and are no longer used. While Hayami has been transcribing and organizing materials that he and his group collected all over Japan, his research concentrated in the areas of Suwa (Hayami, 1973) and Nobi (Hayami, 1992) - central Japan. He rarely used BDS of the Nihonmatsu domain. Instead, Saeko Narimatsu singlehandedly transcribed the original NACs to BDS. With the help of research assistants, she linked individual information from SAC/NAC to BDS and further cross-checked qualitative information of the area from local documents. Based on this laborious work, she published two books on Shimomoriya (Narimatsu, 1985) and Niita (Narimatsu, 1992), which are must-reads for later researchers studying the area. 
Figure 2 BDS (Basic Data Sheet): Household No.112 in Niita, years 1751-1775

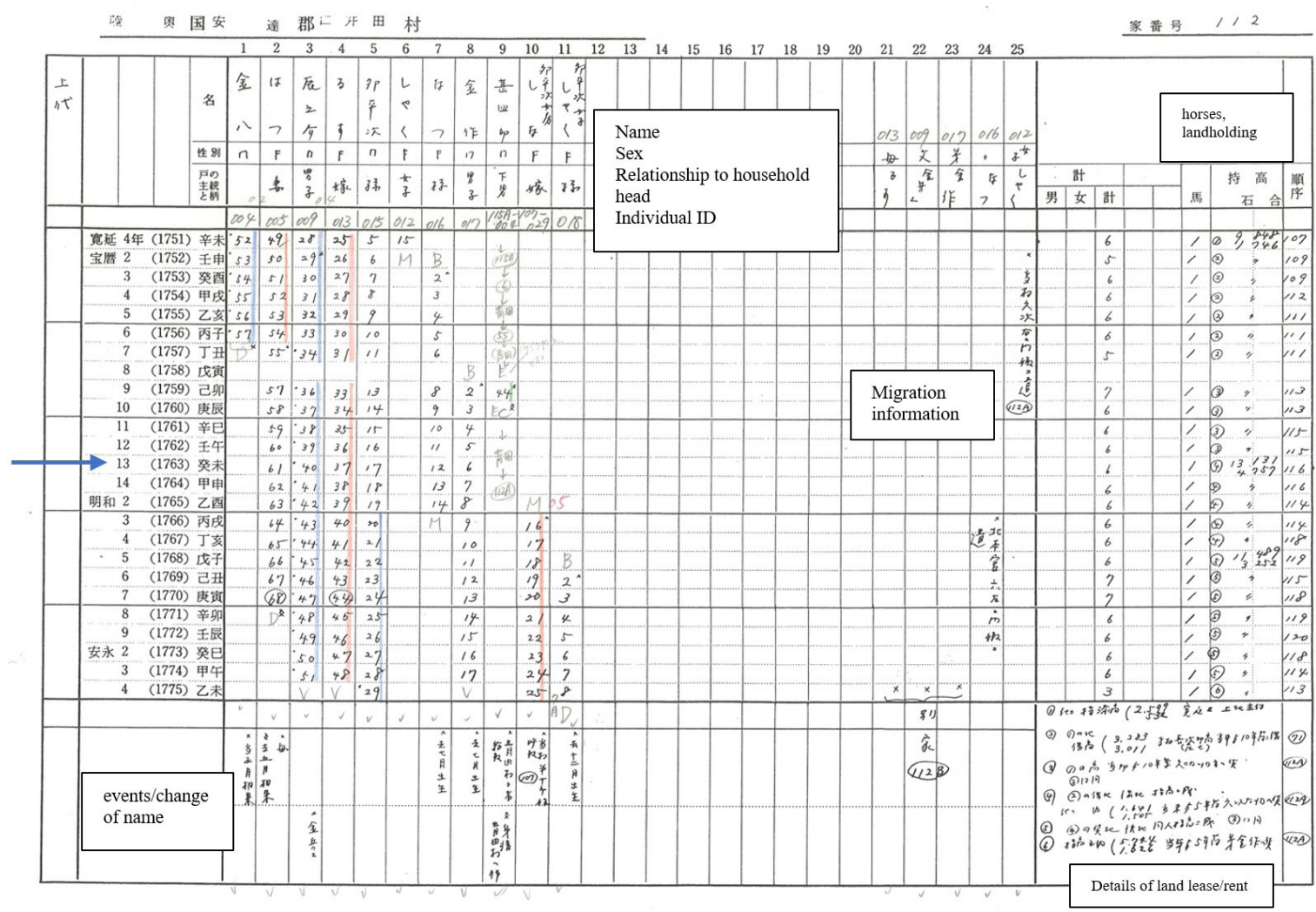

Source: Copy of BDS, Reitaku Archives, Population and Family History Project, Reitaku University.

Note: The blue arrow on the left refers to the household of NAC shown in Figure 1, an example of the NAC source. See text for details.

Map 1 shows the original data collection and ongoing database construction efforts spreading nationwide in Japan, as well as the area of the Xavier Database introduced in this article. The steps described above are also shown in Table 1 in relation to the figures and maps. The Xavier Database is one of the first series of Japanese historical demography datasets constructed by Akira Hayami and the members of the Eurasia Project Japan (EAP-J 1995-2000) ${ }^{3}$ and is the most detailed and vigorously used in the last decades. ${ }^{4}$ Details of Xavier construction are discussed in the next section.

Meanwhile, there are numerous village records entered during and after the time of EAP-J for both longitudinal (red dots in Map 1) and cross-sectional data (orange dots in Map 1) types used in historical demography and family studies. Also, there are plenty of understudied BDS (green dots in Map 1) and microfilms (blue dots in Map 1), now hosted at the PFHP. Since longitudinal data from various locations were not in the same format as the data of the Xavier Database, they were not integrated into one database during the time of EAP-J. Cross-sectional data include those with only one- or twoyear SAC records. While those cross-sectional data have not been utilized for longitudinal research in Japanese historical demography, it has a potential for investigating regional variations as well as fertility dynamics (e.g., Drixler, 2013; Kurosu, 2008).

Eurasia Project of Population and Family History was funded by the Japanese Ministry of Education Grant-in-Aid for Creative Basic Research (PI Akira Hayami). Official members in Japan included at least 37 scholars from various disciplines (history, sociology, anthropology, and information science). Further collections of original sources and numerous data entry, data base construction, as well as collaborative studies were pursued during this period and after. The international collaboration of Eurasia Project (EAP) continued until recently (three volumes are found here: https://mitpress.mit.edu/books/series/ eurasian-population-and-family-history).

4 Another useful database is constructed by a member of the Japanese Eurasia Project, Hiroshi Kawaguchi, DANJURO (http://www.danjuro.jp/). The database includes Aizu villages in Fukushima and is publicly released (registration required). 
There are numerous studies using BDS sheets of areas other than the northeastern ones included in the Xavier Database. To name a few, Hayami's own work of Suwa (1973) and Nishijo and the surrounding villages (1992) and Cornell's work on Yokouchi (1981) in central Japan; and a recent work by Nakajima utilizing a fishing village of Nomo in southwest Japan (2016).

Figure 3 ITS (Individual Tracing Sheet): A female born in 1722 until her death in 1790, Shimomoriya

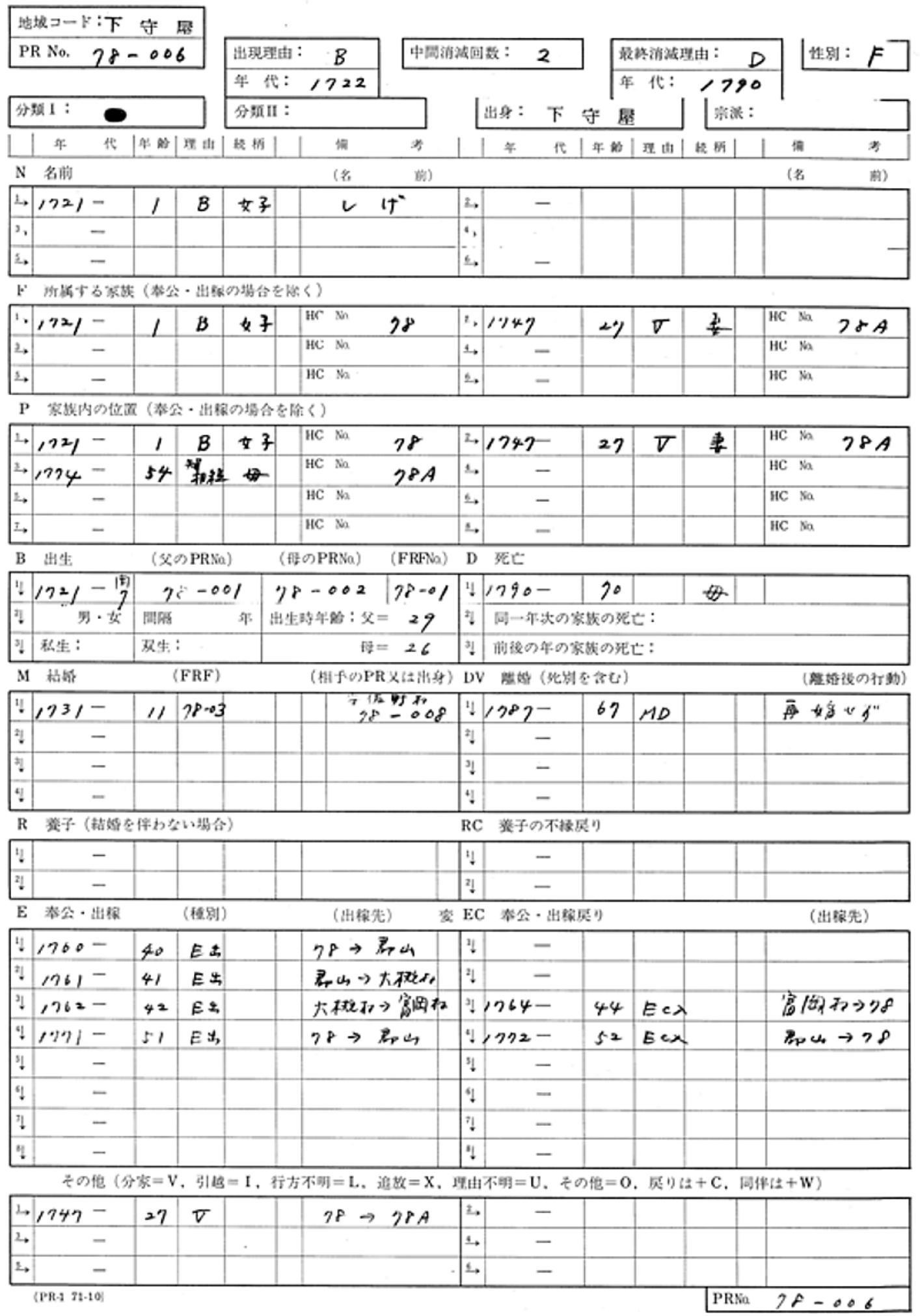

Source: Reitaku Archives, Population and Family History Project, Reitaku University

Note: ITS traces individual moves from the start and end of observation. The form includes $N=n a m e$, $B=$ birth, $M=$ marriage, $R=$ =adoption, E=service, and Other ( $V=$ branching out; I=change of residence, etc.) with year, age, relationship to the household head, and place/households. 
Figure 4

FRF (Family Reconstitution Form): A couple in household 112, Niita 1740-1781

\begin{tabular}{|c|c|c|c|c|c|c|c|c|c|c|c|c|c|c|c|c|c|c|}
\hline 畕 & 6 & & $\mathrm{CF}$ & & 00 & & & & 6 & & & & & & E & 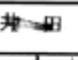 & \begin{tabular}{|l|l|}
$\mathrm{F}$ & $\mathrm{Na}$ \\
$\mathrm{R}$ & $\mathrm{Na}$ \\
\end{tabular} & $112-0 x$ \\
\hline 夹名 & & 2 & 分 & the & 井田敖 & 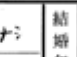 & $\%$ & & $24-11$ & 烈 & " & 28 & & $5 F$ & $\mid$ & 宗 & & $1 / 2-0$ \\
\hline 曹 & $z$ & 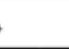 & 5 & 地 F & 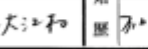 & 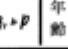 & 14 & & $227-$ & 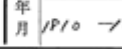 & \begin{tabular}{l|l}
12 & 年 \\
*
\end{tabular} & 84 & ss & 55 & $\mid \begin{array}{l}\mathrm{R} \\
\mathrm{R}\end{array}$ & R. & & $91 / 2-0 / 3$ \\
\hline 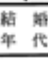 & & 740 & 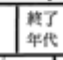 & & \begin{tabular}{l|l|} 
然出 \\
\end{tabular} & $\operatorname{Ka} 3$ & 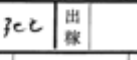 & & & & \begin{tabular}{|l|} 
\\
年 \\
\end{tabular} & & $\begin{array}{l}\lambda \\
\hat{z} \\
\end{array}$ & & & \begin{tabular}{|l|l|} 
岁 & \\
\end{tabular} & \begin{tabular}{|l|l|} 
& 整 \\
\end{tabular} & \\
\hline 号 & 年为 & 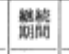 & 䟧表 & 圈 & 尚 & 生野 & 出生年月 & 第策 & 四生藏雨 & 死亡梁月 & 䝒䆛 & 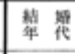 & \begin{tabular}{l|l}
8 \\
8
\end{tabular} & & 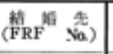 & 宗振 & 角 & 噒 \\
\hline & $\begin{array}{l}15 \\
\text { WF }\end{array}$ & 1.5 & 0 & 1 & $E=\frac{5}{b}$ & 7 & $1742=10$ & 162 & $2-$ & $1945-10$ & 4 & & & & & & & $112-014$ \\
\hline & $\underset{\sim 20}{16}$ & 5 & 1 & 2 & 解平治 & $n$ & $1947-6$ & $2 / 5$ & $s-$ & - & & 1765 & 5.9 & & $1 / 2-95$ & & 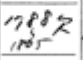 & $1 / 2-0 / 5$ \\
\hline & $\stackrel{21}{\sim 25}$ & 5 & 1 & $3^{3}$ & 毒 7 & $P$ & $1752-7$ & 265 & $5-$ & - & & 1065 & 14 & & 北本客 & & & $1,2-0,6$ \\
\hline & $\underset{\sim 30}{26}$ & 5 & ' & 4 & 金 作 & $n$ & $1358-7$ & 326 & $6-$ & $104 \mid-P$ & 84 & 1704 & 17 & & $1 / 2 B-1 \mid$ & & & $1 / 2-87$ \\
\hline & $\sim 35$ & 5 & 1 & 5 & & & - & & - & - & & & & & & & & \\
\hline & $\stackrel{36}{\sim 40}$ & 5 & 0 & 6 & & & - & & - & - & & & & & & & & \\
\hline & ${ }_{\sim 45}^{41}$ & 5 & 0 & 7 & & & - & & - & - & & & & & & & & \\
\hline & $\sim 50$ & 5 & 。 & 8 & & & - & & - & - & & & & & & & & \\
\hline & $\begin{array}{l}51 \\
\text { 以上 }\end{array}$ & 4,5 & 0 & ${ }^{9}$ & & & - & & - & - & & & & & & & & \\
\hline & 合虾 & 41.0 & 4 & 10 & & & - & & - & - & & & & & & & & \\
\hline & & $\begin{array}{ll}\text { 男 } & 3 \\
女 & \end{array}$ & $\frac{3}{1}$ & ${ }^{11}$ & & & - & & - & - & & & & & & & & \\
\hline & $\sim$ 我 & 35.0 & 4 & ${ }^{12}$ & & & - & & - & - & & & & & & & & \\
\hline & & \begin{tabular}{|l|l} 
男 \\
$女$
\end{tabular} & & 13 & & & - & & - & - & & & & & & & & \\
\hline & & & & 14 & & & - & & - & - & & & & & & & & \\
\hline & & & & 15 & & & - & & - & - & & & & & & & & \\
\hline 實 & & & & 栐 & & 登 & & & 1740 & 11,512 & 褛 & & & & & & & \\
\hline
\end{tabular}

Source: Reitaku Archives, Population and Family History Project, Reitaku University.

Note: The form follows an internationally used format for family reconstitution. The top part of the panel contains information about husband and wife - name, place of birth, age at marriage, month/year of birth and death. No 1-4 in this example are their children with their name, sex, birth year/month, mother's age at birth, and their information on death and marriage. Information about births is summarized for every five years after marriage in the far left of the sheet (Hayami 2001, pp. 74-79).

Map $1 \quad$ Xavier Data and Collections of Japanese Historical Demography Sources

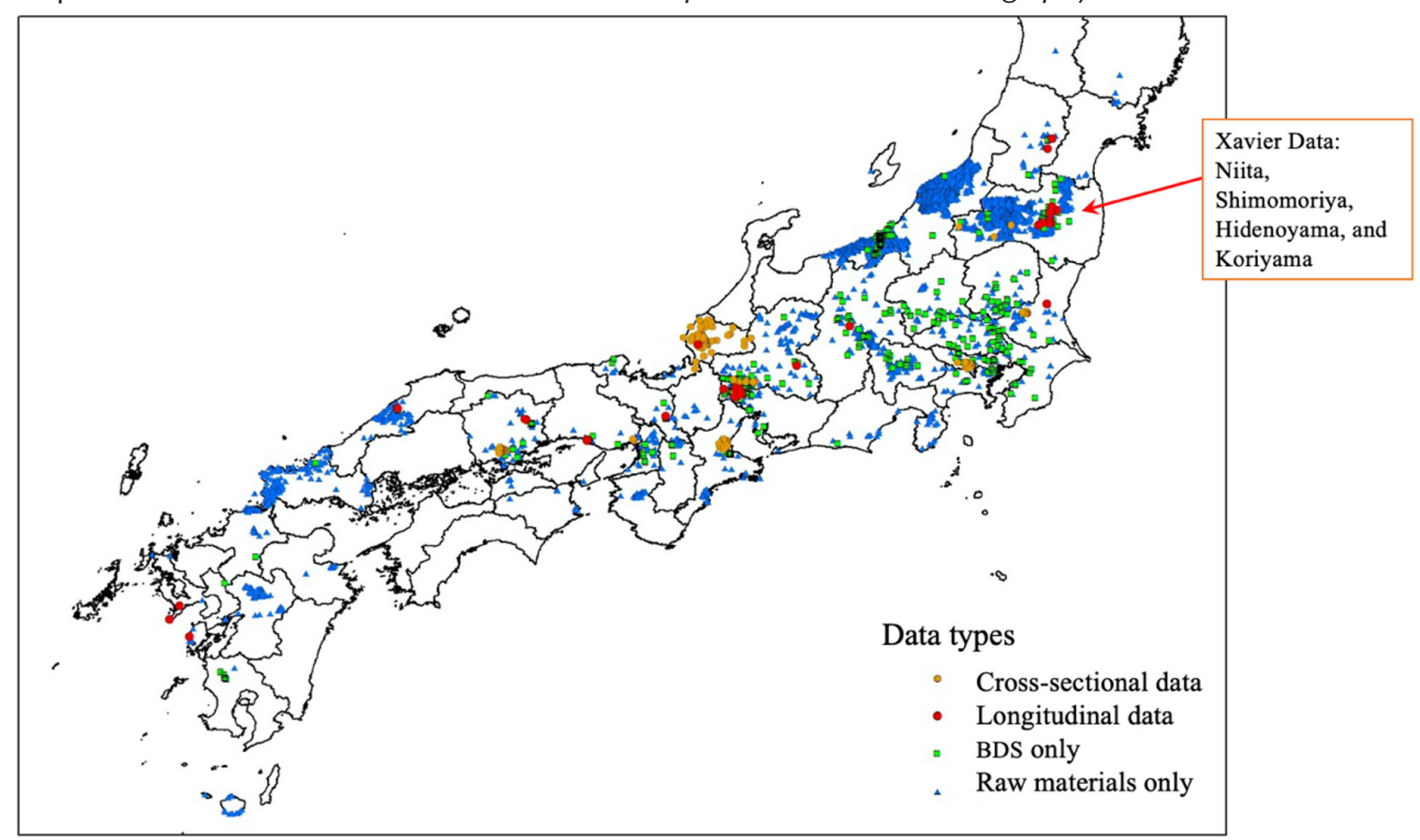

Source: Reitaku Archives, Population and Family History Project, Reitaku University.

Note: See Table 1 for the explanation of the colored dots. 
Table 1 The different steps of database construction in relation to the map and figures

\begin{tabular}{|c|c|c|}
\hline Step & Work & Map/Figure \\
\hline 1 & Making an inventory of all available sources & \\
\hline 2 & Making a micro-film of the sources & Blue dots on Map 1 \\
\hline 3 & $\begin{array}{l}\text { Making a Basic Data Sheet (BDS: systematic transcription of } \\
\text { linked households for a maximum period of } 25 \text { years) }\end{array}$ & Green dots on Map 1, Figure 2 \\
\hline \multirow[t]{3}{*}{4} & The identifiers to individuals are constructed & Figure 2 (Individual ID) \\
\hline & Making an ITS for each individual & (Hayami's earlier trial) Figure 3 \\
\hline & Making a Family Reconstitution Form & (Hayami's earlier trial) Figure 4 \\
\hline 5 & Coding of BDS for Xavier data & Figure 5 \\
\hline $6 \mathrm{~A}$ & $\begin{array}{l}\text { Computerizations of longitudinal data using BDS for villages } \\
\text { with longitudinal records: } \\
\text { Xavier data: based on coding sheets (Figure 5) } \\
\text { Other data: based on BDS (Figure 2) }\end{array}$ & Red dots on Map 1 \\
\hline $6 B$ & $\begin{array}{l}\text { Computerizations of cross-sectional data using BDS or other } \\
\text { transcribed information sheets for villages with one-year records }\end{array}$ & Orange dots on Map 1 \\
\hline
\end{tabular}

Notes: While steps 1-4 were applied to make forms from various sources that remain to digitize, steps 5 and $6 \mathrm{~A}$ are specific to our construction of the Xavier Database, the subject of this article. Basic statistics of the Xavier Database are reported in Table 2.

As of now, Reitaku Archives include microfilmed or paper-copied documents of original SAC/NAC for about 1,870 villages/towns (Step 2). Among them, about 470 villages/towns (about 9960 village/townyears) transcribed in the format of BDS (Step 3). A meta-database of these materials has recently been made available online (limited use) to search the geographic location and type of historical records held at PFHP (Kurosu, 2020).

\section{CONSTRUCTION OF THE XAVIER DATABASE}

No official documentation exists as to what motivated Akira Hayami to initiate and how he pursued the construction of the Xavier Database. However, according to the detailed and yet complicated codebooks, as well as the memories of staff members who worked on the project over decades, the digitization was done with a series of trials and errors. What started in the 1980s remains an evolving process. In this section, we explain how the Xavier Database was transcribed and coded, turned into relational databases (DB2) for separate villages, and finally utilized for variable construction and analysis.

The Xavier data are based on household registers, both NAC and SAC in the northeast Japan. While this article mainly discusses four communities of Nihonmatsu domain (NACs), the Xavier Database also includes villages of the eastern-mountainous area of Fukushima ${ }^{5}$, Aizu, and the village Yanbe in the current Yamagata prefecture (SACs). Numerous studies used the BDS (step 4 in Table 1) of Aizu and Yanbe with some researchers' own data construction efforts (e.g., Hayami \& Okada, 2005; Kinoshita, 2002; Okada, 2006). Also, since the NAC of Koriyama-shimo-machi, the northern town of Koriyama, has too many missing years for longitudinal research, we only include Koriyama-kami-machi, the southern town, in this article.

$5 \quad$ There is yet another village, Sasahara (NAC) in Nihonmatsu. As the size of the village was very small, it was conveniently used to test SQL runs but is not included in this article. 


\subsection{CODING AND DATA ENTRY}

The first trial for the construction of a large longitudinal dataset started in the 1980s. Based on BDS, coders extracted information and organized them by handwriting into three paper forms, named A5, $A 6$ and A7: household events and information (A5), individual age (A6), and individual events and life course (A7, see Figure 5). A5 had 10 household tables of codes and $A 7$ had 17 individual tables of codes - including both time-constant and time-variant information as follows. For households, A5 codebook consists of the following tables: (A) entry and exit of households, (B) de jure or de facto, (C) head's information, (D) servants, (E) village official status, (F) size of household structure, (G) landholding, (H) livestock (horse, cattle), (I) ship ownership, (J) other. For individuals, A7 codebook consists of the following tables: (a) entry and exit of individuals, (b) birth, (c) death, (d) marriage (e) divorce, ( $f$ ) adoption, ( $g$ ) disowning (end of adoption), (h) change of residence, (i) household relationship, (j) change of name, $(\mathrm{k})$ religion, $(\mathrm{I})$ village official task, $(\mathrm{m})$ migration, $(\mathrm{n})$ other event with migration, (o) other event without migration, (p) other information (pregnant, illness, etc.), (q) other information that cannot be classified above.

Figure $5 \quad$ Xavier data format A7 for the coding of individuals

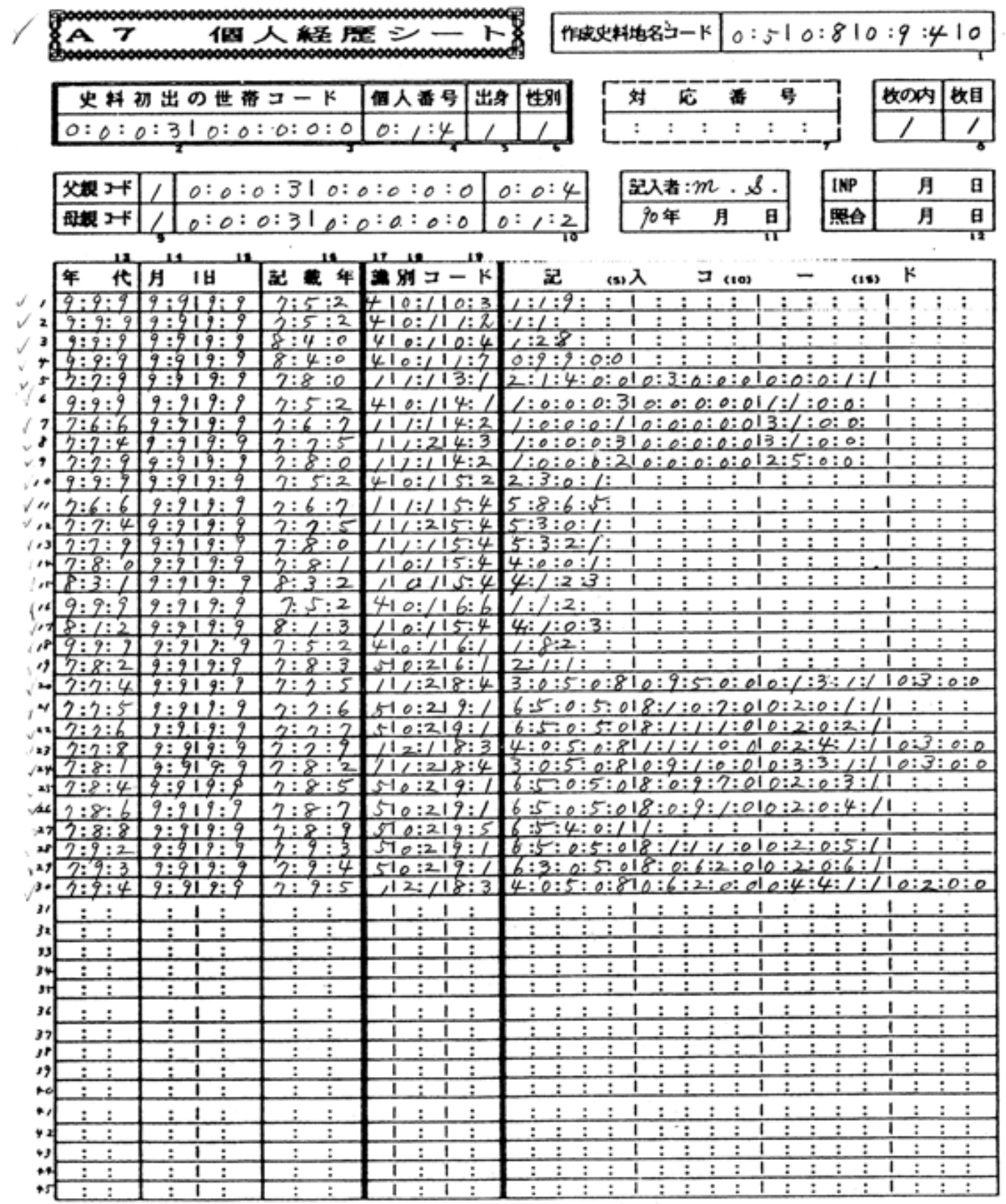

Source: Reitaku Archives, Population and Family History Project, Reitaku University.

Note: See text for details. 
The codes in each table were elaborate and complicated. The origin of the Xavier data predated easy access to computers and even preceded the Japanese word processor for data entry (Ono, 1993). It was vital to convert the information written in BDS into numbers. Therefore, it required detailed codebooks. For example, there are more than 260 codes for the relationship to the household head A7(i) distinguishing kin relations, sex, blood or marriage/adoption relationship. Only trained coders could manually, using paper and pencil, convert detailed information of BDS into thousands of sheets that consist of sheer numbers. While the codes made data entry faster, the steps involved in coding cost enormous time and manpower, as well as an increasing number of errors as more steps are required (Ono, 1993).

The forms $A 5, A 6$ and $A 7$ were then digitized manually using a special computer program. As of today, the coding of 7 villages and 2 towns has been done ${ }^{6}$ but the completion of the data entry was accomplished only for the four communities discussed in this article while the rest was, unfortunately, only partly completed.

\subsection{THE XAVIER DATABASE AND THE EURASIA PROJECT}

The database construction that started in Keio University in the early 1980s was carried over to Nichibunken (Kyoto), with Hayami's move in the late 1980s. It was at this time when the Xavier data were finally put to use. Yoshihiko Ono, associate professor at Nichibuken at the time, converted almost all the files into a relational database separating tables into time-constant and time-dependent tables using DB2 on an IBM platform. With the help of an international EAP member, George Alter, a group of EAP-J members ${ }^{7}$ headed by Yoshihiko Ono studied SQL and database management and started the construction of variables for international comparison. It was first tested on a small village, Sasahara, and then on the two villages of the Xavier Database (Shimomoriya and Niita) which became the basis for the Japanese contribution to the international collaboration of EAP (Tsuya \& Kurosu, 2004, 2010c, 2014). Constructing variables for the EAP model required laborious processing. We used DB2 SQL to write long commands to construct each variable, export them to CSV files, and import and merge them in STATA for village-based analysis. This required advanced statistical and data management skills. It also required high levels of concentration and patience, as we had to go back-and-forth to the $\mathrm{BDS}$ and complicated codebooks whenever an inconsistency arose. The inconsistency could be due to the SQL program, data entry errors of coders, or data entry errors of BDS transcribers. It could even be due to the original documents - mistakes of village officials in Tokugawa period. With all these laborious and time-consuming processes, we were not able to add more than two villages during the entire EAP international collaboration (Kurosu, 2016). In the late 2000s, however, we started to add another village and town from the Xavier Database to our analysis: Hidenoyama and Koriyama.

\subsection{THE XAVIER DATABASE: POPULATION AND SETTINGS}

Table 2 shows a summary of the database for the four communities as well as the information available in those communities. Altogether they cover the span of 162 years with a relatively small number of missing years. In addition to its long coverage, the Xavier Database provides detailed information about demographic characteristics and reason for individual "entrance" under observation (due to birth or immigration) and the month/year of death and other "exits". This is the case even for Koriyama despite the heavy in- and out-migration of the town. Socioeconomic indicators, which are not often recorded in SAC in other places, are also abundant. The two Xavier villages (Niita and Shimomoriya), in particular, are among the best quality historical population panel data available in East Asia (Dong, Campbell, Kurosu, Yang, \& Lee, 2015a).

That said, we need to be careful about one problem inherent in "annual" household registers: the omission of events that happened between registers. NACs of these communities were enumerated annually at the beginning of the third lunar month ${ }^{8}$, an important point to bear in mind for demographic calculations. The timing of marriage, for example, cannot be determined as clearly as many European

6 This includes Shimomoriya, Niita, Hidenoyama, Sasahara, Koriyama-kami, Koriyama-shimo in Nihonmatsu which are complete, and Kuwahara, Kanaizawa, Ishibuse in Aizu, and Yanbe in Murayama. The continuation of data entry unfortunately was disrupted due to Hayami's move from Keio University to the International Research Center for Japanese Studies (Nichibunken).

$7 \quad$ Satomi Kurosu and Hideki Nakazato worked intensively with Ono. Noriko O. Tsuya was instrumental in defining demographic variables proposed in the EAP model for the context of Japan. 
parish registers. If one comes into a household with an annotation of enduke (marriage), the person and his/her partner married sometime between the two register years. An even more serious problem for certain demographic analysis is the omission due to infant death. Those who were born and died between the two registers may not be recorded.

Map 2 shows the location of the four communities. Shimomoriya and Niita were almost totally agricultural with an annual average population size of about 300 and 450, respectively. Hidenoyama, located about $3 \mathrm{~km}$ from the center of the growing market town of Koriyama, became a suburb to this town with an annual average population of about 280. Within the 160 years of observation, however, the area has gone through major famines in the 1780s and 1830s, as well as various epidemics and local disasters. The population trend in Figure 6 reflects the hardship the villages went through. In particular, the two agricultural villages, Shimomoriya and Niita, started to lose their population before the Tenmei famine in the 1780s and did not recover until the 19th century. Such constant decline is not observed in Hidenoyama. As for Koriyama, being a post town ${ }^{9}$ with diverse economic activities, the local population increased over the years from 800 to about 2,600 inhabitants while commercial sectors developed. Koriyama was formally designated as a town (machi) in 1824 and served as the economic as well as the political center of Asaka County. While populations of neighboring villages stagnated, Koriyama experienced a stable population growth. Although it was affected by famines, the population of Koriyama soon recovered because of both in-migration and natural increase. Thus, the Xavier Database shows different population trends between Koriyama and neighboring villages, suggesting an interesting contrast of demographic dynamics between the rural and urban communities.

Table 2 Summary and information of the Xavier Database

\begin{tabular}{|c|c|c|c|c|c|}
\hline Village/Town & $\begin{array}{l}\text { Observation } \\
\text { period }\end{array}$ & $\begin{array}{l}\text { Years of missing } \\
\text { registers }\end{array}$ & \multicolumn{2}{|c|}{ Person - years } & $\begin{array}{c}\text { Unique } \\
\text { individuals }\end{array}$ \\
\hline Niita & 1720-1870 & 4 & \multicolumn{2}{|c|}{74,099} & 4,076 \\
\hline Shimomoriya & 1716-1869 & 9 & \multicolumn{2}{|c|}{53,628} & 2,468 \\
\hline Hidenoyama & $1708-1870$ & 35 & \multicolumn{2}{|c|}{40,036} & 3,046 \\
\hline Koriyama & $1729-1870$ & 18 & \multicolumn{2}{|c|}{219,503} & 18,515 \\
\hline Total & & & \multicolumn{2}{|c|}{346,700} & 28,105 \\
\hline \multicolumn{6}{|c|}{ Information available in four communities } \\
\hline $\begin{array}{c}\text { Demographic } \\
\text { characteristics and } \\
\text { events }\end{array}$ & Inter-personal relations & \multicolumn{2}{|c|}{$\begin{array}{c}\text { Socioeconomic } \\
\text { indicators }\end{array}$} & \multicolumn{2}{|c|}{ Other information } \\
\hline $\begin{array}{l}\text { Age, sex* }{ }^{*} \text {, birth, death, } \\
\text { marriage, divorce, } \\
\text { adoption, service, labor- } \\
\text { migration }\end{array}$ & $\begin{array}{l}\text { Relation to the } \\
\text { household head, } \\
\text { conjugal, sibling, parent- } \\
\text { child, multi-generational }\end{array}$ & \multicolumn{2}{|c|}{$\begin{array}{l}\text { Land-owner or landless } \\
\text { peasants, village } \\
\text { officials, household } \\
\text { landholding, number of } \\
\text { horses }\end{array}$} & \multicolumn{2}{|c|}{$\begin{array}{l}\text { Land rent/lease (Niita } \\
\text { and Shimomoriya only) }\end{array}$} \\
\hline
\end{tabular}

Note: *Sex is inferred based on relationship to the household head and/or name.

9 Post towns, Shukuba-machi in Japanese, were constructed along the major routes/streets in the Tokugawa period. They provided lodgings for public officials, who were forced to periodically travel between their domain and Edo with their vassals; as well as rest for travelers, who were observed more frequently as traveling became more popular throughout the country during this period. Commercial sectors also developed in these towns and catered to the needs of commoners and neighboring villagers (Kurosu, Takahashi, \& Dong, 2017). 
Map 2 Present-day Fukushima prefecture - location of Niita, Shimomoriya, Hidenoyama and Koriyama

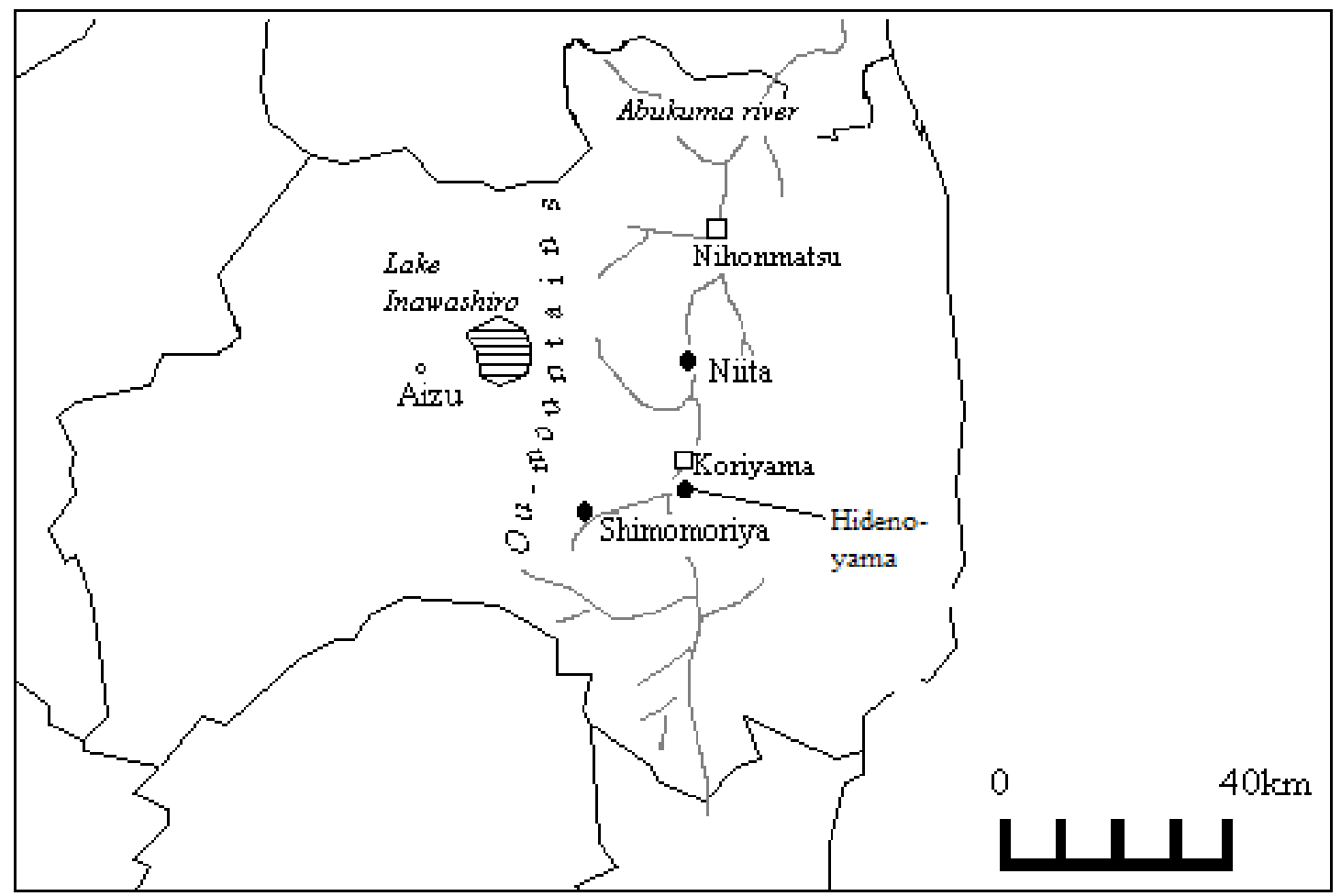

Figure 6 Population trends of Niita, Shimomoriya, Hidenoyama, and Koriyama

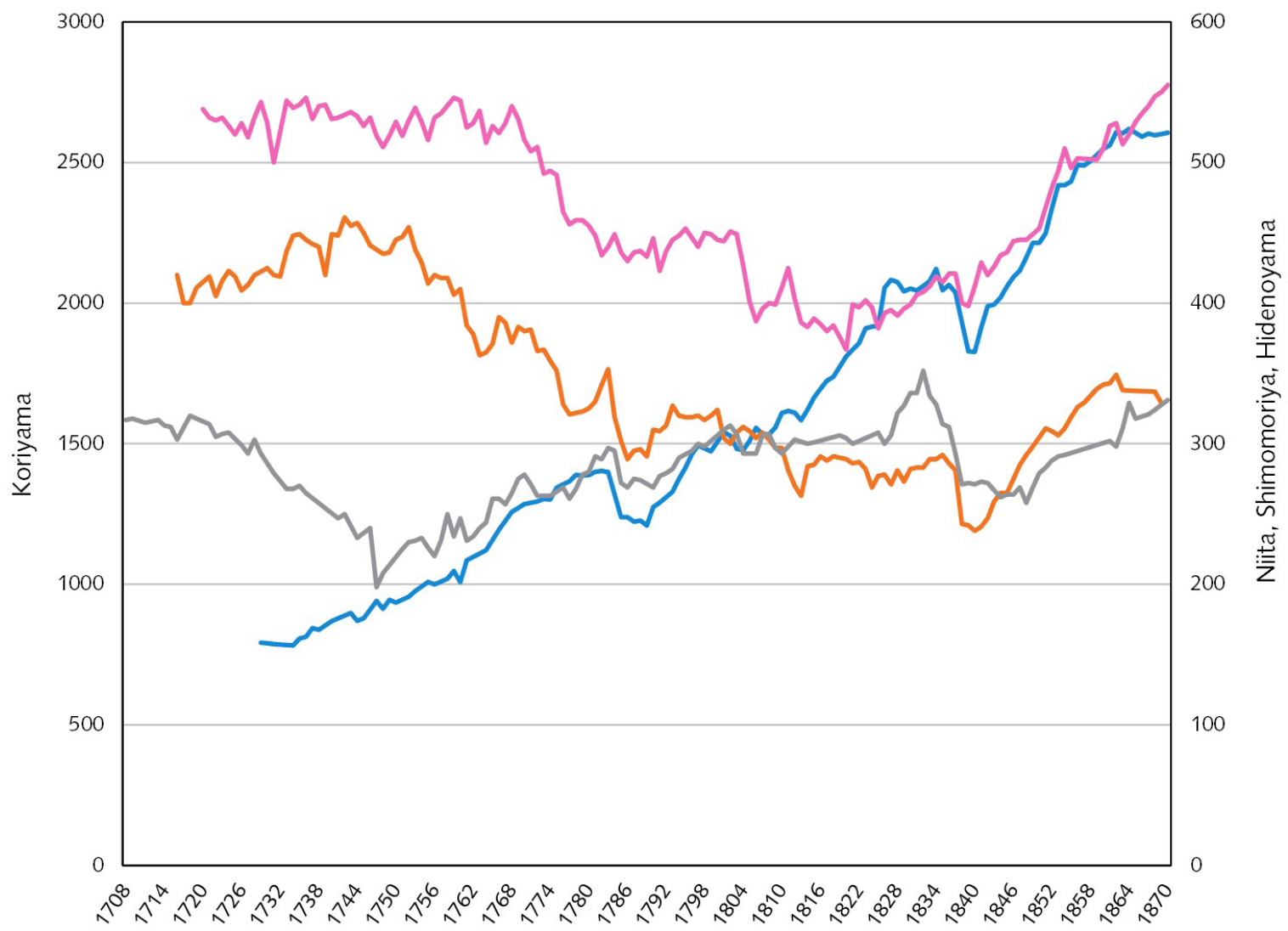

—Koriyama —Niita —Shimomoriya —Hidenoyama 


\section{RESEARCH WITH THE XAVIER DATABASE}

Many advances in the use of the data occurred during the Japanese Eurasia Project. Flat files for analysis based on the two villages, Niita and Shimomoriya, were first made specifically for the international comparison of mortality in EAP (Bengtsson, Campbell, Lee, et al., 2004), and successively for marriage and reproduction (Lundh, Kurosu, et al., 2014; Tsuya \& Kurosu, 2010c). Japanese contributions to these volumes were based on Niita and Shimomoriya (Tsuya \& Kurosu, 2004, 2010c, 2014). Modifying the models used in the international collaboration of EAP, Tsuya and Kurosu produced more detailed studies of mortality and reproduction (Tsuya \& Kurosu, 2005, 2010b). These studies brought new findings about how individual demographic behaviors were influenced by socioeconomic status of households (indicated by landholdings), household context (measured by the presence of co-residing kin), and status in the household (head or closeness to household-head). Further, applying the EAP models but going beyond the topics covered by the EAP international comparison, specific topics for Japan were investigated utilizing the information available in the Xavier Database. These studies emphasized the hierarchy of gender and closeness to household-head in the stem family system; for example, the differential stress caused by the deaths of heads vs. fathers on women and children (Tsuya \& Kurosu, 2002), household context and migration and survivorship (Tsuya \& Kurosu, 2010a, 2013), leaving home, remarriage, divorce, and adoption (Kurosu, 2004, 2007, 2011, 2013). These studies used event history analysis and revealed how the principle of the stem family mediated individual as well as household choices.

Later on, similar models for mortality and marriage were tested with a larger sample by including the village of Hidenoyama (Tsuya \& Kurosu, 2017, 2020). Further, including the town of Koriyama, we started to systematically compare patterns of marriage between village and town populations (Kurosu, Takahashi, \& Dong, 2017). The EAP model was also tested with more rigorous statistical analysis to investigate the association between types of post-marital residence and reproduction (Dong \& Kurosu, 2017). These studies demonstrated "northeastern characteristics" of marriage and reproduction influenced by the norm of "primogenitor" (succession by first child regardless of sex) that distinguished the area, going even beyond rural and urban differentials.

Researchers who shared knowledge and methods for working with the Xavier Database flourished in the Japanese Eurasia Project. They used various methods (both descriptive and statistical) to empirically tackle issues of family history which had been confined to institutional or household-based approaches. Comprehensive studies of Koriyama and Niita appeared in two Ph.D. dissertations using the Xavier Database and complementary local historical records (Hirai, 2008; Takahashi, 2005) ${ }^{10}$. Takahashi (2005) was one of the first who systematically studied a booming town, Koriyama, and indicated the importance of understanding migration as well as domanial population policy in the demographic model. The urban graveyard theory was examined but found not to be applicable for this town. Hirai (2008) studied the dataset of Niita from a comprehensive approach to individual life courses and households and found that households became more resilient and stable towards the 19th century.

Xavier data allowed a dynamic approach from individual life course perspectives providing new findings and detailed accounts for marriage, adoption, and their outcomes (Hirai, 2006a, 2015; Kurosu, 1997, 1998, 2007, 2009, 2011, 2012b; Takahashi, 2012), living arrangements (Hirai, 1998; Nakazato, 1999 , 2009; Ochiai, 2001, 2006c), leaving home (Kurosu, 2004), service and labor migration (Nagata, 2001, 2004; Ochiai, 2002; Takahashi, 2019), and name changing (Nagata, 1999, 2009). These studies found how individual life courses were stratified by the rule of stem family organization, i.e., the overall aim of the continuity of households that shaped individual demographic events in order to overcome various demographic and economic constraints. The Japanese historical family was further examined in an international comparison aimed at comparing stem family societies in Europe and Japan (FauveChamoux \& Ochiai (Eds.), 2009). Individual-level studies of marriage, name-changing and livingarrangement based on the Xavier Database (Kurosu, 2009; Nagata, 2009; Nakazato, 2009) reveal the dynamics of individual life courses within the stem family system.

The longitudinal data of the Xavier Database also offered dynamic approaches to "old" questions about household structure, continuity, and succession. Okada applied the studies of household cycles to Nihonmatsu villages and asserted a modified version of Hammel-Laslett in order to show the clear

10 Yet another dissertation by Okada (2006) demonstrated the developmental cycle of households in Aizu domain proposing a modified Hammel-Laslett model. She did not directly use the Xavier Database but BDS of Aizu villages from which the Xavier Database was constructed. 
cyclical change of Japanese households as well as succession strategies (1998, 2000, 2002). The stem family orientation of the peasant family became clear, particularly among land-owning peasants. Hirai identified characteristics of the continuity of households spanning over a century (e.g., 2003, 2006b).

This series of studies on individual life courses and household cycles written in both English and Japanese became the core achievements of the Japanese Eurasia Project (Ochiai, 2006b) and affected the fields of historical demography and family history and sociology in various ways. First, the novelty of findings sustained by detailed and statistically sound analysis painted clear and fresh pictures of commoners' life courses and families in the 18-19th centuries. For example, universal marriage was followed by flexible divorce and remarriage. Early marriage did not necessarily bring an early start of childbearing. Fertility was extremely low because of the practice of sex-selective infanticide, and adoption compensated for demographic constraints when sons or daughters were lacking. These demographic behaviors were in accordance with peasants' strategy of keeping the stem family intact. These new findings were surprises to family sociologists influenced by the western tradition of family modernization, which emphasizes monolithic and developmental changes. They also made demographers and historians reconsider the importance of households and the stem family system in understanding the contrasting population dynamics in Japan compared with other countries (e.g., Ochiai, 2009; Saito, 1998, 2000).

Studies based on Xavier data opened possibilities for broadening research into two directions: longitudinal and regional approaches. First, within about 160 years of observation, a general improvement of climate and development of cash crops as well as sericultural industries in the region boosted development of the regional economy. Various improvements in demographic behaviors are observed, particularly related to females: increase in the female age of marriage (Kurosu, 2012a; Kurosu, Takahashi, \& Dong, 2017; Tsuya \& Kurosu, 2014), decline of female infant mortality (Tsuya \& Kurosu, 2004), and increase of reproduction (Tsuya \& Kurosu, 2010b, 2010c). Also, homogenization of age at marriage and shortening of length between marriage and divorce were associated with increasing household size and complexity making households more stable towards the end of Tokugawa period. Hirai calls the process "emergence" of Japanese traditional family that emphasizes its continuity and the stem family household (Hirai, 2003, 2006a, 2006b, 2008).

Second, the characteristics of northeastern population and family were clarified empirically in the comparative framework of regional variation in Japan (e.g., Kurosu, Tsuya, \& Hamano, 1999; Ochiai (Ed.), 2006a; Okada \& Kurosu, 1998; Takahashi \& Kurosu, 2020). While fertility was generally low in early modern Japan, it was very low in the northeast (Takahashi, 2005; Tsuya \& Kurosu, 2010b, 2010c). The survival rate tends to be lower than other studied areas of Japan (Tsuya \& Kurosu, 2004). Marriage was early, universal, and more flexible than in the rest of Japan (Kurosu, Tsuya, \& Hamano, 1999). Labor migration before marriage delayed marriage in central Japan, but in the northeast migration took place after marriage, making marriage a safety net for households to have them return for sure after service (Nagata, 2001, 2004). Researchers argue that the strategy was intended to increase the working-age population in households to overcome environmental hardships in the northeastern region (Hayami, 2009; Hayami \& Kurosu, 2001). These arguments, however, are only based on limited village studies of the northeast, Nishijo in central, and Nomo in the southwestern Japan ${ }^{11}$, and await further investigation.

\section{CONCLUSION}

This article introduced one of the major databases of Japanese historical demography, called the Xavier Database, which includes individual-level longitudinal data of populations in three villages and one town of the current Fukushima prefecture between 1708 and 1870. We discussed the long and complicated process used by the founder of Japanese historical demography, Akira Hayami, and his colleagues to collect, transcribe, code, and finally put the content of the historical population registers into a database. We also reviewed the content and studies that flourished domestically and internationally using these data in the last two decades.

11 Databases for Nishijo (NOBI) and Nomo (NOMO) were constructed during the Japanese Eurasia Project, and also gave opportunities for developing sociological and/or statistical investigations using historical records (e.g., Nakajima, 2016; Nakazato, 2004). 
During the last decade, new attempts are being made into at least four directions. First, the two villages of the Xavier Database, Niita and Shimomoriya, are harmonized and used for several comparative studies with other East Asian historical populations from northeastern China, Taiwan, and Korea a collaborative effort sometimes referred to as the East Asia Project or EAP II (Dong et al., 2015a). The standardization and harmonization of different East Asian population datasets, an effort led by Hao Dong in collaboration with each relevant research team, have enabled detailed, systematic comparative studies about similarities and differences in population dynamics and family histories within East Asia (e.g., Dong, 2016; Dong, Campbell, Kurosu, \& Lee, 2015b; Dong, Kurosu, \& Lee, 2019; Dong, Manfredini, Kurosu, Yang, \& Lee, 2017). Second, although still being at the experimental stage, comparative studies of early modern and post-modern Japanese families reveal some interesting resiliency or continuity of Japanese family. These studies bridge Tokugawa and contemporary Japan applying the same model for divorce and marriage to Xavier data and contemporary survey data (Kurosu \& Kato, 2018; Tsuya \& Kurosu, 2019). Third, there is a new effort coding and adding more information to the original Xavier Database from records of migration and land-lease. In the last few years, we identified geographic locations of 5,000 migration records from the Xavier Database. We can track where migrants came from and went to and the reasons for migration such as service, marriage, or adoption. This will add a spatial dimension to the longitudinal analysis (Kurosu, 2020; Kurosu, Takahashi, \& Nagaoka, 2017; Nagaoka, Kurosu, \& Takahashi, 2020). Other unique information of the Xavier Database not used until now is land lease/rent and livestock. We added more details of the land transactions (from whom, to whom) for the village of Niita. This has started to show us how land transactions were associated with social mobility and equality as well as demographic patterns of the villages (Arimoto \& Kurosu, 2020). We are also constructing a database on livestock based on the records of horses and cattle in BDS. This will make additional useful information about agricultural conditions and the peasant economy related to population dynamics (Takahashi, 2018). Finally, efforts led by Satomi Kurosu with the cooperation of Hao Dong have been undertaken at PFHP to integrate various data collections and sources to advance larger-scale, longitudinal research of family behavior and population history in early modern Japan ${ }^{12}$. The comparative and interdisciplinary approach applied to records of thousands of lives promises new understanding of our history and the resilience of people to socioeconomic and environmental changes.

As the foundation for all, the Xavier Database still inspires us with interesting research topics and possibilities going beyond the field of historical demography and the family. We are extremely grateful for the inexhaustible research opportunities provided by the database.

Thank you, Francisco Xavier! Thank you, Akira Hayami!!

\section{ACKNOWLEDGEMENTS}

We are grateful to Akira Hayami (1928-2019) for leaving us amazing sources and datasets, and for his leadership, insights, and guidance in the studies of historical demography. Part of this article is based on the paper we co-authored with Hayami and presented at the 2019 Annual Meeting of the Social Science History Association in Chicago, IL, "Constructing Individual-Level Longitudinal Data for Japanese Historical Population: Challenges and Opportunities". We would like to thank Saeko Narimatsu and all the current and former project members who contributed to collecting, transcribing, and organizing old documents as well as entering and cleaning the data sources. We would like to thank Shoko Hirai, Hideki Nakazato, Aoi Okada, and Atsushi Nagaoka, researchers who worked with Xavier data; Toshiko Mochida, Hirofumi Ohnuma, and Yuriko Kikuchi, research assistants at PFHP for preparing this draft.

12 This project is supported by "Social and geographic mobility and life course: Studies using multigenerational panel data" Grants in Aid for Scientific Research (B), Japan Society for the Promotion of Science (KAKEN 19H01569). 


\section{REFERENCES}

Arimoto, Y., \& Kurosu, S. (2020). Tokugawa Nihon noson no shisan-bunpai: Nihonmatu-han Niitamura (1720-1870) wo jireini [Asset allocation in rural Tokugawa Japan: The case of Niita village of Nihonmatsu domain, 1720-1870]. Economic Review, 71(3), 237-258.

Bengtsson, T., Campbell, C., Lee, J. Z., et al. (2004). Life under pressure: Mortality and living standards in Europe and Asia, 1700-1900. Cambridge, MA: MIT Press.

Cornell, L. L. (1981). Peasant family and inheritance in a Japanese community: 1671-1980: An anthropological analysis of local population registers (Doctoral dissertation). Johns Hopkins University, Baltimore, MD.

Cornell, L., \& Hayami, A. (1986). The Shumon Aratame Cho: Japan's population registers. Journal of Family History, 11(4), 311-328. doi: 10.1177/036319908601100401

Dong, H. (2016). Patriarchy, family system and kin effects on individual demographic behavior throughout the life course: East Asia, 1678-1945 (Doctoral dissertation). The Hong Kong University of Science and Technology, China.

Dong, H., Campbell, C., Kurosu, S., Yang, W., \& Lee, J. Z. (2015a). New sources for comparative social science: Historical population panel data from East Asia. Demography, 52(3), 1061-1088. doi: 10.1007/s13524-015-0397-y

Dong, H., Campbell, C., Kurosu, S., \& Lee, J. Z. (2015b). Household context and individual departure: The case of escape in three "unfree" East Asian populations, 1700-1900. Chinese Journal of Sociology, 1(4), 515-539. doi: 10.1177/2057150X15614547

Dong, H., \& Kurosu, S. (2017). Postmarital residence and child sex selection: Evidence from northeastern Japan, 1716-1870. Demographic Research, 37, 1383-1412. doi: 10.4054/DemRes.2017.37.43

Dong, H., Kurosu, S., \& Lee, J. Z. (2019, November). The making of missing girls: Evidence from northeast China and Japan, 1708-1909. Presentation at the annual meeting of Social Science History Association, Chicago, IL.

Dong, H., Manfredini, M., Kurosu, S., Yang, W., \& Lee, J. Z. (2017). Kin and birth order effects on male child mortality: Three East Asian populations, 1716-1945. Evolution of Human Behavior, 38(2), 208-216. doi: 10.1016/j.evolhumbehav.2016.10.001

Drixler, F. (2013). Mabiki: Infanticide and population growth in eastern Japan, 1660-1950. Oakland, CA: University of California Press.

Fauve-Chamoux, A., \& Ochiai, E. (Eds.). (2009). The stem family in Eurasian perspective: Revisiting household societies, 17th-20th centuries. Bern: Peter Lang.

Hayami, A. (1973). Kinsei noson no rekishi-jinko-gaku-teki kenkyu shinshu Suwa-chiho no Shumon Aratame-cho bunseki [Historical demographic study of early modern agricultural villages: Analysis of Shumon-Aratame-cho in Suwa region, Shinshu]. Tokyo: Toyo-Keizai-Shimpo-sha.

Hayami, A. (1979). Thankyou, FranciscoXavier:Anessay in the use of micro-dataforhistoricaldemography of Tokugawa Japan. Keio Economic Studies, XVI (1-2), 65-81. Retrieved from https://koara.lib. keio.ac.jp/xoonips/modules/xoonips/detail.php?koara_id=AA00260492-19790001-0065

Hayami, A. (1992). Kinsei Nobi-chiho no jinko [Population of early modern Nobi area]. Tokyo: Sobunsha.

Hayami, A. (2009). Population, family and society in pre-modern Japan (Collected papers of twentieth-century Japanese writers on Japan). Kent: Global Oriental.

Hayami, A. (2001). The historical demography of pre-modern Japan. Tokyo: University of Tokyo Press. (Originally published in Japanese by Iwanami Shoten Publishers, 1997)

Hayami, A., \& Kurosu, S. (2001). Regional diversity in demographic and family patterns in preindustrial Japan. Journal of Japanese Studies, 27(2), 295-321. doi: 10.2307/3591968

Hayami, A., \& Okada, A. (2005). Population and household dynamics: A mountainous district in northern Japan in the Shûmon Aratame Chô of Aizu, 1750-1850. The History of the Family, 10(3), 195-229. doi: 10.1016/j.hisfam.2005.03.007

Hirai, S. (1998). Kinsei niokeru yome-shutome no kyoju-keitai: Nihonmatu-han Niita-mura no jirei yori [Living arrangements between wives and mothers-in-law in rural northeastern Japan, 17201870. Kazoku-Kenkyu-Sosho [Nara Journal of Family Studies], 4, 3-20.

Hirai, S. (2003). Kinsei tohoku-noson niokeru "ie" [Emergence of the "ie" or the Japanese "traditional" family in early modern Japan: A historical-demographic analysis]. Soshioroji [Sociology], 47(3), 3-18.

Hirai, S. (2006a). Kekkon no kinshitsu-ka to "ie" no kakuritsu: Tohoku-noson no baai [Homogenization of marriage and the establishment of the "le" : A case of northeastern farming village]. In E. Ochiai (Ed.), Tokugawa Nihon no raifu kosu [Life courses of Tokugawa Japan]. Kyoto: Minerva-shobo. 
Hirai, S. (2006b). le no kakuritsu to kasan no keisho: Mutsu-no-kuni Adachi-gun Niita-mura no jirei [The establishment of the family and the succession of family property: A case study of Niita, Adachi County, Mutsu province]. In E. Ochiai (Ed.), Tokugawa no kazoku to chiiki-sei [Family and regionality of Tokugwa Japan]. Kyoto: Minerva-shobo.

Hirai, S. (2008). Nihon no kazoku to raifu kosu "ie" seisei no Rekishi-shakai-gaku [Family and life course in Japan: Historical sociology of the emergence of the "ie"] (Doctoral dissertation). Kyoto: Minerva-shobo.

Hirai, S. (2011). Tohoku-nihon niokeru ie no rekishi-jinko-gaku-teki bunseki [A historical demographic analysis of households in northeastern Japan: Focus on population trends in the eighteenth and nineteenth centuries]. In K. Kasaya (Ed.), 18-seiki Nihon no bunka-jokyo to kokusaikankyo [Japan in the eighteenth century: Cultural conditions and international environment] (pp. 215231). Kyoto: Shibunkaku Shuppan.

Hirai, S. (2013). Kinsei-sonraku niokeru ie no henyo [Changes in the ie system in early modern Japanese villages]. Shakaigaku Zasshi [Sociological Review of Kobe University], 30, 78-90.

Hirai, S. (2015). Tohoku-noson niokeru kekkon pataan no henyo: 18-19 seiki no rekishi-jinko-gakuteki bunseki [Transformation of marriage patterns in rural northeastern villages: A historical demographic analysis of the 18th and 19th centuries]. In K. Kasaya (Ed.), Tokugawa-shakai to Nihon no kindai-ka [Tokugawa society and the modernization of Japan] (pp. 407-423). Kyoto: Shibunkaku Shuppan.

Kinoshita, F. (2002). Kindaika-izen no Nihon no jinko to kazoku: Ushinawareta sekai karano tegami [Population and family before Japanese modernization: Letter from the lost world]. Kyoto: Minerva-shobo.

Kurosu, S. (1997). Adoption as an heirship strategy? A case from a northeastern village in pre-industrial Japan. Japan Review, 9, 171-189. Available from http://www.jstor.org/stable/25791007

Kurosu, S. (1998). Long way to headship, short way to retirement: Adopted sons in a northeastern village in pre-industrial Japan. The History of the Family, 3(4), 393-410. doi: 10.1016/S1081602X(99)80254-1

Kurosu, S. (2004). Who leaves home and why: Daughters and sons in two northeastern villages, 1716-1870. In F. van Poppel, M. Oris, \& J. Z. Lee (Eds.), The Road to independence: Leaving home in western and eastern societies, 16th-20th centuries (pp. 243-271). Bern: Peter Lang.

Kurosu, S. (2007). Remarriage in a stem family system in early modern Japan. Continuity and Change, 22(3), 429-458. doi: 10.1017/S026841600700642X

Kurosu, S. (2008). Filling gaps in Japanese historical demography: Marriage, fertility, and households in nineteenth-century rural Japan. Sungkyun Journal of East Asian Studies, 18(1), 43-70. Retrieved from https://sjeas.skku.edu/\#/search/detail/4163?offset=1

Kurosu, S. (2009). Marriage, divorce and remarriage in a stem family system: Women in two northeastern Japanese villages, 1716-1870. In A. Fauve-Chamoux \& E. Ochiai (Eds.), The stem family in Eurasian perspective: Revisiting household societies, 17th-20th (pp. 327-344). Bern: Peter Lang.

Kurosu, S. (2011). Divorce in early modern rural Japan: Household and individual life course in northeastern villages, 1716-1870. Journal of Family History, 36(2), 118-141. doi: 10.1177/0363199011398428

Kurosu, S. (2012a). Mukotori-kon to yomeiri-kon: Tohoku-noson niokeru joshi no kekkon to raifu kosu [Uxorilocal vs. virilocal marriage: Marriage and life-course among women in northeastern rural villages]. In S. Kurosu (Ed.), Rekishi-jinko-gaku karamita kekkon, rikon, saikon [Marriage, divorce and remarriage from the perspective of historical demography] (pp. 57-79). Kashiwa: Reitaku University Press.

Kurosu, S. (Ed.) (2012b). Rekishi-jinko-gaku karamita kekkon, rikon, saikon [Marriage, divorce and remarriage from the perspective of historical demography]. Kashiwa: Reitaku University Press.

Kurosu, S. (2013). Adoption and family reproduction in early modern Japan. The Economic Review, 64(1), 1-12. doi: 10.15057/25877

Kurosu, S. (2016). Historical demography going 'glocal': Eurasia project and Japan. In K. Matthijs, S. Hin, J. Kok, \& H. Matsuo (Eds.), The future of historical demography: Upside down and inside out (pp. 60-62). Leuven/Den Haag: Acco. Retrieved from https://soc.kuleuven.be/ceso/fapos/ publications/the-future-of-historical-demography-upside-down-and-inside-out

Kurosu, S. (2020). Reitaku archives no kinsei jinko-keizai shiryo-Hayami Akira-shi kizo shiryou no meta-database kochiku [Reitaku archives and early modern demographic and economic data: Construction of meta-database for Hayami collection]. Gengo to Bunmei [Language and Civilization], 18(2), 27-38. 
Kurosu, S., \& Kato, A. (2018, April). Socioeconomic factors of divorce: A comparative analysis of early modern and contemporary Japan. Presentation at the annual meeting of Population Association of America, Denver, CO.

Kurosu, S., Takahashi, M., \& Dong, H. (2017). Marriage, household context and socioeconomic differentials: Evidence from a northeastern town in Japan, 1716-1870. Essays in Economic and Business History, 35(1), 239-263. Retrieved from https://www.ebhsoc.org/journal/index.php/ ebhs/article/view/49

Kurosu, S., Takahashi, M., \& Nagaoka, A. (2017). Xavier data kara hukugen suru ido hisutori: Kinsei shomin no jinko ido shiryo [Migration history reconstructed based on Xavier data]. Gengo to Bunmei [Language and Civilization], 15, 139-150. Retrieved from https://reitaku.repo.nii. ac.jp/?action=pages_view_main\&active_action=repository_view_main_item_detail\&item_ id=992\&item_no=1\&page_id=13\&block_id=29

Kurosu, S., Tsuya, N. O., \& Hamano, K. (1999). Regional differentials in the patterns of first marriage in the latter half of Tokugawa Japan. Keio Economic Studies, 36(1), 13-38. Retrieved from https://koara. lib.keio.ac.jp/xoonips/modules/xoonips/detail.php?koara_id=AA00260492-19990001-0013

Lundh, C., Kurosu, S., et al. (2014). Similarity in difference: Marriage in Europe and Asia, 1700-1900. Cambridge, MA: MIT Press. doi: 10.7551/mitpress/9780262027946.001.0001

Nagaoka, A., Kurosu, S., \& Takahashi, M. (2020). Kinsei tohoku niokeru Mutsu-no-kuni Nihonmatsuhan choson no jinko ido no kukanteki hirogari [Migration and geographical spread in earlymodern Nihonmatsu in the northeastern region]. Gengo to Bunmei [Language and Civilization], 18(2), 17-6. Retrieved from https://reitaku.repo.nii.ac.jp/?action=pages_view_main\&active_ action=repository_view_main_item_detail\&item_id=1263\&item_no=1\&page_id=13\&block_ $\mathrm{id}=29$

Nagata, M. L. (1999). Balancing family strategies with individual choice: Name changing in early modern Japan. Japan Review, 11, 145-166. Available from http://www.jstor.org/stable/25791040

Nagata, M. L. (2001). Labor migration, family and community in early modern Japan. In P. Sharpe (Ed.), Women, gender and labour migration: Historical and cultural perspectives (pp. 60-84). London: Routledge.

Nagata, M. L. (2004). Leaving the village for labor migration in early modern Japan. In F. van Poppel, M. Oris, \& J. Z. Lee (Eds.), The Road to independence: Leaving home in western and eastern societies, 16th-20th centuries. Bern: Peter Lang.

Nagata, M. L. (2009). Name changing patterns and the stem family in early modern Japan: Shimomoriya. In A. Fauve-Chamoux \& E. Ochiai (Eds.), The stem family in Eurasian perspective: Revisiting household societies, 17th-20th (pp. 361-378). Bern: Peter Lang.

Nakajima, M. (2016). Kinsei seinan-kaison no kazoku to chiikisei: Rekishi-jinko-gaku kara kindai no hajimari wo tou [Family and community in the early-modern southwestern fishing village: Questioning the beginning of modernization from historical demography]. Kyoto: Minerva-shobo.

Nakazato, H. (1999). Kinsei tohoku noson niokeru koreisha no kyojyukeitai: Oyako ichiji dokyo no pataan [Living arrangements of the elderly in early modern rural Japan: Transitions between presence and absence of coresiding children]. Kazoku-Kenkyu-Sosho [Nara Journal of Family Studies], 5, 3-20.

Nakazato, H. (2004). Rireishonaru database niyoru teikei deta no sakusei: Shumon-Aratamae-Cho no tokei bunseki no tameni [Creating flat-files for analysis using relational database: For the statistical analysis of Shumon-Aratame-Cho]. Riron to Hoho [Theory and method], 19(2), 197-212. doi: 10.11218/ ojjams.19.197

Nakazato, H. (2009). Transitions in living arrangements over the life course: Aging in a rural village in Japan, 1716-1869. In A. Fauve-Chamoux \& E. Ochiai (Eds.), The stem family in Eurasian perspective: Revisiting household societies, 17th-20th (pp. 345-360). Bern: Peter Lang.

Narimatsu, S. (1985). Kinsei tohoku noson no hitobito: Oshu Asaka-gun Shimomoriya-mura [People in a northeastern agricultural village in early modern Japan: The village of Shimomoriya, Asaka county, Ou region]. Kyoto: Minerva-shobo.

Narimatsu, S. (1992). Edo-jidai no Tohoku noson: Nihonmatsu-han Niita-mura [Agricultural villages in northeastern Tokugawa Japan: The village of Niita in Nihonmatsu domain]. Tokyo: Dobunkan.

Ochiai, E. (2001). Myth and reality of Asian traditional families: Living arrangement of the elderly in Tokugawa Japan. Journal of Asian-Pacific Studies, 9, 7-21.

Ochiai, E. (2002). Kinsei josei hoko-nin nitotteno kon'in to shussan: Mutsu-no-kuni Asaka-gun Shimomoriyamura Ninbetsu-Aratame-Cho no suryo-bunseki [Marriage and childbirth among female servants in the early modern period: A quantitative analysis of population registers of Shimomoriya]. Josei RekishiBunka-Kenkyujo-Kiyo [Bulletin of Institute for Women's History and Culture], 10, 1-14. 
Ochiai, E. (Ed.) (2006a). Tokugawa no kazoku to chiiki-sei [Family and regionality of Tokugwa Japan]. Kyoto: Minerva-shobo.

Ochiai, E. (2006b). Yurashia purojekuto no tassei: Rekishi-jinko-gaku to kazokushi [The achievement of the Eurasian Project: Historical demography and family history]. Shakaikagaku Kenkyu [Journal of Social Science], 57(3-4), 57-80. Retrieved from https://repository.dl.itc.u-tokyo.ac.jp/records/17193\#. YXEVWBrP2bh

Ochiai, E. (2006c). Korei-sha no 'kodomo' tono dokyo: Tohoku-noson niokeru kaiso to kyoju-keitai [Elderlies living with 'children': Socioeconomic status and residential structure in rural northeastern villages]. In E. Ochiai (Ed.), Tokugawa no raifu kosu [The life course of Tokugawa Japan] (pp. 183-205). Kyoto: Minerva-shobo.

Ochiai, E. (2009). Two types of stem household system in Japan: The ie in global perspective. In A. FauveChamoux \& E. Ochiai (Eds.), The stem family in Eurasian perspective: Revisiting household societies, 17th-20th (pp. 287-326). Bern: Peter Lang.

Okada, A. (1998). Joto-gata koshu no tokucho: Mutsu-no-kuni Adachi-gun Niita-mura Ninbetsu-AratameCho wo chushin toshite [Characteristics of the succession of heads: Based on Ninbetsu-Aratame-Cho of Niita, Adachi county, Mutsu province]. Teikyo Shakaigaku [Teikyo Sociology], 11, 109-135.

Okada, A. (2000). Kinsei-nomin-shakai niokeru setai saikuru: Nihonmatu-han ni-kason no shiryo wo mochiite [The cycle of household structure in early modern peasant society]. Shakaigaku Hyoron [Japanese Sociological Review], 51(1), 136-152. doi: 10.4057/jsr.51.136

Okada, A. (2002). Kinsei-nomin-kazoku niokeru katoku no keisho to sono senryaku, Mutsu-no-kuni Asakagun Shimomoriya-mura Ninbetsu-Aratame-Cho wo chushin toshite [Succession and strategy among early modern peasants' family: Based on NAC of Shimomoriya, Asaka country, Mutsu province]. In A. Hayami (Ed.), Kindai ikoki no kazoku to rekishi [Family and history in the modern transition]. Kyoto: Minerva-shobo.

Okada, A. (2006). Kinsei Sonraku-shakai no le to Setaikeisho: Kazoku-ruikei no Hendo to Kaiki [le and household succession in early modern agricultural society: Variation and regression of family types (Doctoral dissertation). Tokyo: Chisen-shokan.

Okada, A., \& Kurosu, S. (1998). Succession and the death of the household head in early modern Japan: A case study of a northeastern village,1720-1870. Continuity and Change, 13(1), 143-166. doi: $10.1017 /$ S0268416098003099

Ono, Y. (1993). Bunka-kei no keisanki riyo II: Deta-nyuryoku no yuzaa intaafeisu, rekishi-jinko-gaku no baai [Computer utilization for humanities II: User interface for data entry, the case of historical demography]. Nihon Kenkyu [Bulletin of International Research Center for Japanese Studies], 8, 165-182.

Saito, O. (1998). Two kinds of stem-family system? Traditional Japan and Europe compared. Continuity and Change, 13(1), 167-186. doi: 10.1017/S0268416098003087

Saito, O. (2000). Marriage, family labour and the stem family household: Traditional Japan in a comparative perspective. Continuity and Change, 15(1), 17-45. doi: 10.1017/S026841609900346X

Takahashi, M. (2005). Zaigo-machi no rekishi-jinko-gaku: Kinsei ni okeru chiiki to chiho toshi no hatten [The historical demography of Koriyama, a post town: The development of a local town within a community in early modern times] (Doctoral dissertation). Kyoto: Minerva-shobo.

Takahashi, M. (2012). Zaigo-machi no kekkon to saikon [Marriage and remarriage in a local post town]. In S. Kurosu (Ed.), Rekishi-jinko-gaku karamita kekkon, rikon, saikon [Marriage, divorce and remarriage from the perspective of historical demography] (pp. 119-139). Kashiwa: Reitaku University Press.

Takahashi, M. (2018, August). The use of horses in the Nihonmatsu domain, Tohoku district in Japan. Paper presented at the session "Subsistence, Sustenance, and Changing Living Spaces: Comparative Studies of Eurasian Economies from the 16th-20th centuries" at the World Economic History Congress, Boston, MA.

Takahashi, M. (2019). The labour market and labour migration in small post towns in early modern Japan: The relationship between a town and its outlying villages in the northeastern domain of Nihonmatsu in the eighteenth to nineteenth centuries. In N. Okuda \& T. Takai (Eds.), Gender and family in Japan (pp. 3-31). Springer.

Takahashi, M., \& Kurosu, S. (2020). Kinsei Nihon no jinko to kiko [Population and climate in early modern Japan]. In T. Nakatsuka, K. Kamatani, \& K. Watanabe (Eds.), Kiko hendo kara kinsei wo minaosu: Suryo, sisutemu, gijutsu [Reviewing the early modern period from the perspective of climate change] (pp. 51-96). Kyoto: Rinsen-shoten.

Tsuya, N. O., \& Kurosu, S. (2002). The mortality effects of adult male death on women and children in agrarian household in early modern Japan. In R. Derosas \& M. Michel Oris (Eds.), When dad died: Individuals and families coping with family stress in past societies (pp. 261-299). Bern: Peter Lang. 
Tsuya, N. O., \& Kurosu, S. (2004). Mortality and household in two Ou villages, 1716-1870. In T. Bengtsson, C. Campbell, J. Z. Lee, et al. Life under pressure: Mortality and living standards in Europe and Asia, 1700-1900 (pp. 253-292). Cambridge, MA: MIT Press.

Tsuya, N. O., \& Kurosu, S. (2005). Demographic responses to short-term economic stress in eighteenth and nineteenth-century rural Japan: Evidence from two northeastern villages. In R. Allen, T. Bengtsson, \& M. Dribe (Eds.), Living standards in the past: New perspectives on well-being in Asia and Europe (pp. 427-460). Oxford: Oxford University Press.

Tsuya, N. O., \& Kurosu, S. (2010a). To die or to leave: Demographic responses to famines in rural northeastern Japan, 1716-1870. In S. Kurosu, T. Bengtsson, \& C. Campbell (Eds.), Demographic responses to economic and environmental crises (pp. 79-106). Kashiwa: Reitaku University. Retrieved from http://iussp.org/sites/default/files/AllArticles.pdf

Tsuya, N. O., \& Kurosu, S. (2010b). Reproduction and family building strategies in early modern Japan: Evidence from two northeastern farming villages. The History of the Family, 15(4), 413-429. doi: 10.1016/j.hisfam.2010.05.004

Tsuya, N. O., \& Kurosu, S. (2010c). Family, household, and reproduction in two northeastern Japanese villages, 1716-1870. In N. O. Tsuya, F. Wang, G. Alter, J. Z. Lee, et al. Prudence and pressure: Reproduction and human agency in Europe and Asia, 1700-1900 (pp. 249-285). Cambridge, MA: MIT Press.

Tsuya, N. O., \& Kurosu, S. (2013). Social class and migration in two northeastern villages 1716-1870. The History of the Family, 18(4), 434-455. doi: 10.1080/1081602X.2013.815126

Tsuya, N. O., \& Kurosu, S. (2014). Economic and household factors of first marriage in two northeastern Japanese villages, 1716-1870. In C. Lundh, S. Kurosu, et al. Similarity in difference: Marriage in Europe and Asia, 1700-1900 (pp. 349-391). Cambridge, MA: MIT Press.

Tsuya, N. O., \& Kurosu, S. (2017, June). Socioeconomic and family factors of first marriage: A comparative analysis of early modern and contemporary Japan. Presentation at the Population Association of Japan, Tohoku University, Japan.

Tsuya, N. O., \& Kurosu, S. (2019). Patterns and factors of first marriage: A comparative analysis of early modern and contemporary Japan. Keio IES Discussion Paper Series (No. DP2019-012). Tokyo: Keio University. Retrieved from https://ies.keio.ac.jp/en/publications/11327/

Tsuya, N. O., \& Kurosu, S. (2020, November). Household socioeconomic status and mortality at different stages of life: Evidence from three northeastern Japanese villages, 1708-1870. Presentation at the Population Association of Japan, Saitama Prefectural University, Japan.

Tsuya, N. O., Wang, F., Alter, G., Lee, J. Z., et al. (2010). Prudence and Pressure: Reproduction and human agency in Europe and Asia, 1700-1900. Cambridge, MA: MIT Press. 